$<$ running head recto> Livelihoods and Child Welfare

$<$ running head verso> B. Inder et al.

<first page footer>@ 2017 The Authors. African Development Review @ 2017 African Development Bank. Published by Blackwell Publishing Ltd, 9600 Garsington Road, Oxford OX4 2DQ, UK and 350 Main Street, Malden, MA 02148, USA.

<running footer>@ 2017 The Authors. African Development Review ( 2017 African Development Bank

\title{
Livelihoods and Child Welfare among Poor Rural Farmers in East Africa
}

\section{Brett Inder, Carolyn Kabore, Sharna Nolan, Katy Cornwell, Diana Contreras Suarez, Anne Crawford and Joseph Kamara*}

* Brett Inder, Centre for Development Economics and Sustainability, Monash University VIC 3800, Australia; e-mail: brett.inder@monash.edu. Carolyn Kabore, World Vision International, 1 Vision Drive, Burwood East VIC 3151, Australia; e-mail: Carolyn_kabore@wvi.org. Sharna Nolan, Sharna Nolan Consulting, www.sharnanolan.com; e-mail: sharna.nolan@gmail.com. Katy Cornwell, Centre for Development Economics and Sustainability, Monash University VIC 3800, Australia; e-mail: katy.cornwell@ monash.edu. Diana Contreras Suarez, Centre for Development Economics and Sustainability, Monash University VIC 3800, Australia; e-mail: diana.contreras.suarez@monash.edu. Anne Crawford, 1 Vision Drive, Burwood East VIC 3151, Australia; e-mail: anne.crawford@ worldvision.com.au. Joseph Kamara, 693 Ning Group Office Park, Somhlolo Road, Mbabane, Swaziland; e-mail: joseph_kamara@wvi.org

Abstract: This paper explores aspects of household livelihoods and welfare among poor rural farmers in Kenya, Uganda and Tanzania. The models use data from an extensive cross-sectional household survey undertaken in 2013 of over 3,500 rural households. Interest is in identifying the main input constraints to improving farm production, with a particular focus on labour constraints, and the impacts of farm production on the well-being of children - their food security, resilience and engagement in school. The results show low agricultural productivity, and that yields per hectare decline significantly with land size. This is consistent with poor quality land and a labour constraint in agricultural activity: there is insufficient return on labour to justify further investment of effort to cultivate the land, given the typically low-input, labour-intensive farming methods. Food shortage models also show that adult labour is relatively unproductive: having more adults in the household produces little reduction in the incidence of food shortages. Overall the results suggest some directions for development interventions, by highlighting that the critical issue for economic and social development among these communities is to improve the productivity of both land and labour.

This is the author manuscript accepted for publication and has undergone full peer review but has not been through the copyediting, typesetting, pagination and proofreading process, which may lead to differences between this version and the Version of Record. Please cite this article as doi:10.1111/1467-8268.12248 


\section{Introduction}

In a developing country setting, poor rural households are among the most vulnerable, not least because the product of their agricultural activities is inextricably linked to household welfare outcomes like food security and child development (Christiaensen and Subbarao 2005; Ravallion, 2009). Where markets exist, agricultural products provide the primary source of income, and in the common scenario where markets are absent or limited, production and consumption are almost perfectly aligned, highlighting this vulnerability (Fafchamps, 2010). It thus follows that development programmes targeted at improving agricultural productivity among smallholder farmers have the potential to produce significant welfare gains and reductions in poverty among rural households (Valdes and Foster, 2011).

There is an extensive literature studying the link between agricultural activity and poverty among poor rural households (see the overview in Schneider and Gugerty, 2011). Theoretical and empirical evidence at the aggregate and household level is mixed, in part because increased productivity can drive down prices of agricultural outputs, benefiting consumers but not producers (Christiaensen $e t$ al., 2011; Datt and Ravallion, 1998). In particular, there is little empirical evidence that identifies a clear link between agricultural productivity and welfare among rural African communities.

Exceptions include mixed evidence for a range of countries studied in chapters of Bresciani and Valde (2007) and Minten and Barrett (2008) for Madagasgar, and Dzanku (2015) for Ghana. The most definitive empirical analysis is found in Dzanku (2015), who considers this question using a sample of households from Ghana, defining welfare as an index aggregating across several dimensions.

Consistent with most previous work, Dzanku finds that while higher productivity does produce improved welfare outcomes, the returns are practically small. Meaningful poverty reduction would require dramatic increases in productivity. Nonetheless, Tirivayi et al. (2016) observed that welldesigned smallholder agricultural interventions that target the poor increased household asset holdings, productivity and livelihoods.

This paper adds to the limited empirical evidence on African countries, using a large sample of households across three countries in sub-Saharan Africa. The cross-country sample not only gives us a larger sample than most previous studies, it also allows more generalizable conclusions to be reached. While earlier work focused on the impact of agricultural productivity on household income/consumption (e.g. Minten and Barrett, 2008), we focus more on welfare outcomes, particularly child welfare. The analysis will study a few specific welfare outcomes separately, rather than using the aggregate index approach of Dzanku (2015). This allows us to identify potentially differential effects on the various outcomes, such as children's health and educational engagement and food security.

A specific focus of this paper is on identifying the extent of labour constraints in improving farm production, and the impacts of variations in farm production on the well-being of children - their food security, resilience and engagement in school. By looking at variations in these inputs across households, we can identify some of the key constraints to meeting the basic needs of children and households.

The results point to the need for investments that improve the productivity of labour; this in turn makes for greater efficiencies in the use of land. Priority needs to be given to practices that improve quality of soil, water and vegetation management to ensure more is produced with the same or less labour input. The empirical models suggest this will have direct benefits to children, freeing up time to attend school, and to adults, enabling them to pursue other income producing activities.

The paper starts in Section 2 with a conceptual model based on standard economic theory. The data is introduced in Section 3, followed by some descriptive statistics in Section 4 and main empirical models in Section 5. A summary of results and implications is given in Section 6.

\section{Conceptual Model}

The theory of agricultural households in development economics (see Taylor and Adelman, 2003 for a useful overview) provides a framework for understanding the unique issues facing these households, as both producers and consumers of their own outputs. These households face an analogous set of issues with supply and demand for labour, and trade-offs in use of time. For example, having more people in the household means a greater potential supply of labour, and hence production, but also 
more demand for outputs/consumption. There are impacts on children too, as their time spent in schooling takes them away from the supply of labour.

Consider first the production side of a household's activities. In a standard production function framework, agricultural output of the household will depend on key inputs, land, labour and capital. These inputs interact in potentially complex ways, but the feature we will focus on particularly is with the supply of labour and how it affects the productivity of land. With low-technology farming practices, work is labour intensive, and potentially households will face labour constraints. For example, Immink and Alarcon (1993) find that household labour availability is a key determinant of crop yields. This constraint particularly applies if working-age adults also have carer responsibilities for children and elderly household members.

Previous work exploring household composition and productivity touches on many issues. Early work by Bunswanger and Rosenzweig (1986) suggests household composition ought to have little impact on land size or productivity, but this is contradicted in later studies, including when gender differences are considered (Shapiro, 1990; Peterman et al., 2011; Meinzen-Dick et al., 2011). The empirical model in this paper will allow us to identify the interaction of household composition and land size in determining productivity of land, an important contributor to household income.

The standard approach to conceptualizing household consumption behaviour in the agricultural household model is within a utility maximizing framework, where utility depends on levels of consumption of food and other goods, and on leisure, together with a range of household characteristics that would affect utility, such as quality of housing, social status, and potentially many others (Taylor and Adelman, 2003). The agricultural household, faced with constraints on time/availability of labour, will maximize utility via a balancing decision, trading off time spent working, which produces more output, income and hence food, against time spent in leisure. The production function specifies how time in work translates to production and hence food consumption. The utility function provides the mechanism for households making the marginal decision between work and leisure.

The empirical models in this paper focus on the link from production to welfare, taking into account household assets and composition. Assets provide an indicator of long-term wealth status, and serve as some form of insurance against fluctuations in income, which can severely affect welfare (Townsend, 1995). In particular, it is argued that land is critical to poverty reduction, even beyond the increased production that a larger plot of land can generate (Jayne et al., 2003). The models will allow us to test this association, and to show that indeed land in itself provides a greater protection than the production it generates.

\section{Data and Methods}

The data is based on a set of household surveys undertaken in 2013 in Kenya, Uganda and Tanzania, with two regions per country. Data were collected during a baseline study for World Vision's East Africa Farmer Managed Natural Regeneration (FMNR) project (World Vision Australia, 2015). The purpose of the survey was to describe the current status and trends of socioeconomic and biophysical variables impacting household level income, food security, soil fertility and crop/livestock productivity, and to provide a pre-intervention baseline for key project indicators.

Agricultural productivity in the areas studied is very low. Most households are not producing sufficient food to meet their nutritional needs. This is not unusual for dryland/rainfed smallholder farming systems in semi-arid regions especially in Eastern Africa which is prone to disasters such as droughts and floods, as well as various crop diseases. In addition to these periodic disasters and crop diseases, it appears much of the land in the studied areas has been subject to widespread degradation.

Further details of sample design are available in Nolan (2013). Multi-stage cluster sampling was used, with random household selection via a probability-proportional-to-size approach. The survey instrument was standard across all countries. Various quality assurance measures we taken, such as thorough enumerator training, survey piloting and other quality checks.

Table 1 shows the sample sizes for each region where the baseline survey was undertaken, and gives a brief contextual description of the areas under consideration in each of the three countries. In all study areas, soils were highly depleted, fields were cropped and grazed without fallow and regional deforestation rates were high (Nolan, 2013). 
Table 1 near here

\subsection{Data Reliability}

The survey and analysis in this paper relies on self-reported measures of variables where households are typically unable to accurately estimate the values required in the survey questions. This includes variables like the size of land, or the number of kilograms of a particular crop harvested in the previous season, tree numbers and so on, where farmers are less likely to have precise knowledge or will have very inaccurate recall. If these errors are relatively small and random, they are not likely to cause any systematic bias in the analysis, but sometimes they can be substantial, and systematic. To accommodate this possibility, robust estimation techniques are required. These are described further in Section 3.3 below.

\subsection{Data Aggregation}

As with most surveys of agricultural households, questions are designed to elicit details of crop production by crop type, and of animal stocks by type of animal. However, modelling farm production and yields requires aggregating production of the various crops and stocks of the different animals, so that we have an indication of total production.

First, consider crop production: the challenge is with how to aggregate production across a range of crops. There are a few options for how to weight each of the crops in the aggregate measure: using nutritional value of the crop (usually calories per kg), or using land use requirements. We choose the latter option in this case because we are particularly interested in the determinants of productivity of the agricultural land households are working with. This is an adaptation of the approach used to compare livestock production, where a set of standard livestock units allows quantities of different animals to be compared (Njuki et al., 2011). To our knowledge this approach has not previously been applied to aggregating crop production.

The starting point of the aggregation across crops is some benchmark for crop yields per hectare (ha). We use FAOSTAT (www.faostat3.fao.org) data on 2013 average Kenya crop yields for the five main crops (representing close to 98 per cent of production) reported in the survey - see Table 2. For cross-country comparability, it is necessary to use a common benchmark for all survey areas; we have chosen Kenyan data as the benchmark as it represents a typical production profile for rainfed mixed crop and livestock farming systems across the region.

Table 2 near here

For each household we take the ratio of production of each of these five crops to the equivalent average yield. This gives the number of hectares of land that would be required to produce this amount of each crop, if the household produced at the FAO average yield for Kenya. We can then add across all the five main crops, and obtain total crop production, defined as the total number of hectares that would be required to produce this farm's output, if the household produced at the FAO average yield for each crop. This value is directly comparable across households, with units being number of hectares.

A ratio of this measure of crop production to actual land area gives a measure of crop yields, compared to the FAO average Kenyan farm. A ratio of 1.0 represents an 'average yield farm'. If less than 1.0, this farm needs more land to produce their output than a farm with average yields, so their land is less productive than the FAO average.

We adopt the same approach to aggregating livestock values across different animal types. The benchmark is the standard FAO 'livestock units', which are based on average body weight converted into metabolic weight. A value of 1.0 represents one average beef cow in North America. Livestock units for sub-Saharan Africa are most relevant (Chilonda and Otte, 2006), and are given in Table 3. Weighting the quantities of each type of animal that households own by these livestock units gives a total stock of livestock, with units being 'livestock units'.

Table 3 near here

\subsection{Methods}

As noted, the survey responses contain some outliers and potentially unreliable responses to certain important questions. The main issue to deal with is the relatively few extreme and unrealistic outlier values. If ignored, these outliers can have undue influence on model estimates. 
Instead of eliminating observations when their values are 'extreme', which is always a subjective exercise, where possible we rely on robust measures and techniques (well described in Rousseeuw and Leroy, 1987). To summarize the characteristics of a variable, we use median instead of mean, and the quartiles/interquartile range instead of standard deviation. For multivariate models, where possible we use median regression, a variation on standard regression techniques that is designed to be robust to outliers in the data. While standard regression estimates slope parameters that best predict the conditional mean of the dependent variable, median regression is designed to predict the median (conditional on the given values of the explanatory variables).

For discrete outcomes (such as whether all school-aged children are attending school), it is not possible to estimate a model using median regression, due to the binary nature of the dependent variable. For these cases, we estimate a linear probability model (LPM) with outliers eliminated, and the coefficients are estimated marginal effects. A strong case is made for use of the linear probability model in, for example, Angrist and Pischke (2009), instead of probit or logit models, not least because of the robustness of the LPM, compared to the tight assumptions that are made in derivation of the probit and logit models.

\section{Descriptive Statistics}

Table 4 shows summary statistics for a range of key household output and outcome variables. The reported statistics show a great deal of variation between households in most variables, as well as wide differences across regions, reflecting in part the different types of primary activities in different areas (e.g. crop versus grazing).

Table 4 near here

First, consider farm size. This shows clearly that most farms are very small, with median farm size of around 2 ha in each country. Around 25 per cent of farms were very small, being less than 1 ha in size in virtually every region.

Next, we look at stocks of trees. This is an indicator of the level of deforestation and its likely effects on soil preservation and quality, a critical factor in agricultural productivity (Diao and Sarpong, 2011; Codjoe and Dzanku, 2009). The median number of trees per household across the whole sample is only 5 . In some regions there are significantly more, with the median being 19 for the Kiambogoko region of Kenya, and 10 for Uganda. The 75th percentile values confirm the relatively low number of trees across most households. The vast majority of households report less than 20 trees.

A similar story can be told if we look at trees per hectare for each region. Tree density is relatively low. For example, 75 per cent of households in Kenya and in Uganda had less than 20 trees per hectare, and 4 or less in Tanzania. Within Kenya, a number of households have relatively high tree density in Kambogoko, while the vast majority of households in Mogotio have a tree density of virtually zero. To give some benchmark for comparison, an evaluation of the World Vision Talensi Farmer Managed Natural Regeneration project in Ghana (Weston et al., 2015, Weston et al., 2013) found that typical baseline tree densities were around 5 trees per hectare, similar to the values found in this sample. Implementation of FMNR practices over three years led to an increase in tree density to 57 per hectare on cropland and over 2000 per hectare on communal forest land (Weston et al., 2013, 2015). The low tree density in the locations studied here suggests they are prime target areas for agro forestry, forest rehabilitation and afforestation programs (FAO, 2011, Boffa, 1999).

A further consequence of this high level of deforestation is its impact on access to firewood. Households depend almost exclusively on firewood to provide heat for cooking. Collecting firewood is a time-consuming activity: the median household in this survey reports spending 2 hours per day collecting firewood, while around 10 per cent report spending 5 hours or more per day. Almost 70 per cent of respondents reported that firewood is less available now than 3 years ago. Reij et al. (2009) highlight how the labour-saving benefits and enhanced income opportunities through FMNR practices have empowered women in Niger.

Next, we look at stock of animals, defined as livestock units. Again, it is notable how low the livestock levels are, especially outside Kenya. For Tanzania, the median household has only 0.05 LU which is the equivalent of 5 chickens per household, or one cow or horse for every 10 households. 
Turning next to crop production, Table 4 shows total crop production in hectares, and also crop yield per hectare. The overall median production of 0.55 ha is relatively low, with almost 75 per cent of households producing less than the equivalent of one hectare's worth of production. There is also a sizeable proportion with very low production; a 25th percentile of 0.19 suggests these households are producing around one-third of the output as that of the (already low) median household.

To get some idea of the magnitude of these production levels from the point of view of a subsistence household, we focus on maize. Crop-by-crop analysis of the data shows median household production of maize in Kenya is $725 \mathrm{~kg}$ per year, and this represents about two-thirds of all staple crop production for the typical Kenyan household. Allowing for the standard loss of weight in processing and converting this to calorific value, this is equivalent to a little over 4,800 calories per household per day, or 800 calories per person for a median household size of six people. This represents less than 40 per cent of the standard calorific requirement of 2,100 calories per day. Production of other staple crops (a further one-third of production in kgs) would improve this slightly, but would add around 200 calories per person per day at best. These are worryingly low levels of food production, but not out of context for the region that is chronically food insecure.

Worse still, our calculations are based on the median household in Kenya, which Table 4 shows is the country with the highest levels of standardized crop production. Extending these calculations, a typically sized household would need a crop production of at least 1.5 in hectare units, to be able to produce sufficient calories for their daily needs. Virtually no households in Tanzania and Uganda achieve this minimum, and only about 25 per cent are able to in Kenya.

The crop yield calculations tell us about yields compared to an average Kenyan household based on FAO data, measured as crop production (in hectares) per hectare of land area. Virtually all households in all three countries are less productive than the FAO average. The median household has a very low yield, only 28 per cent of the average. Kiambgoko region in Kenya provides the only exception to this rather bleak picture.

The latter rows of Table 4 show the summary statistics for the household welfare indicators that are analysed in the regression models reported in Section 5. Four measures are used:

- Resilience: In this study we proxy resilience by the capacity to provide for children's needs for all of shoes, clothing and bed covers without external financial assistance. According to this definition, 55 per cent of the respondent households classified as 'resilient'. A measure based on a richer set of indicators would be more desirable, but this was the best available measure given the constraints of this survey.

- Food shortages: Food security has been shown to be a critical issue to human development (e.g. Conceicao et al., 2011). The survey asks households whether they experienced any serious food shortages over the past year, and the number of months of shortages. Overall 76 per cent of households reported shortages, with a median of 4 months of shortages each year; 25 per cent of households experienced shortages for 8 months or more. There is some geographic variation in the incidence of food shortages - as many as 93 per cent of households experienced shortages in the Kotido region of Uganda, compared to 'only' 58 per cent in other areas of Uganda.

- School attendance: Despite some progress in enrolment rates across Africa, progress has been slow, and reach into rural areas is challenging (Gakusi, 2010). In the sample of households, only 43 per cent of households have all school-aged children regularly attending school, with the vast majority attending primary school. Attendance rates vary enormously by region, with only 21 per cent of households in Kotido (Uganda) having all children in school, while the rate is a much better 79 per cent for households in the Mogotio region of Kenya.

\section{Quantitative Models of Farm Production and Child Welfare Outcomes}

While causal relationships are difficult to identify conclusively in a cross-section study, there is value in building multivariate models of key output and outcome variables. A multivariate model at the least allows us to show associations between variables after controlling for the effects of other factors, and in some cases, an argument can be advanced for these associations to be causal.

Models will seek to explain farm production variables such as crop production and yields, and livestock assets, and a second set of models of the various household welfare measures. 


\subsection{Production Models}

The key explanatory variables in the agricultural production models are described here.

- Land area (ha): One would expect more land to result in higher levels of production.

- Tree density: Tree density (trees per ha) is included to capture the potential benefits of trees for land quality and hence production.

- Household composition: It is common in subsistence agricultural households for household size to be an important contributor to production. This reflects both a demand effect (more people means more food requirements), and a supply effect (more people to work the land, greater carer responsibilities). We include a variety of variables here, to capture differential effect of children, working-aged adults and elderly residents on the agricultural outputs of the household. We also include an interaction of land size and number of working-aged adults, as an attempt to explore the interactions between supply of labour and of land. The specific interpretations of these variables are incorporated into the discussion that follows.

\section{Crop Production}

Consider the first results column of Table 5. The estimates show that households with more land have significantly higher levels of crop production $(t$-statistic $=13.36)$. The coefficient of 0.061 , however, suggests that one extra hectare of land translates to only 0.061 ha-equivalent of crop production. If there were no other constraints on households (such as available labour) one would expect a coefficient of close to 1.0. The small estimate suggests that for households who have more land, they are not able to fully use the additional land. The primary reasons for this are likely to include limitations on cropping inputs especially livestock manure or other fertilizer, labour shortages or highly degraded soils.

Table 5 near here

Tree density has a positive and significant effect on crop production, however the coefficient of 0.00022 is small. This suggests that for a median sized farm of 2 ha, an additional 10 trees per hectare would produce increased crop production of 0.0044 ha-equivalent, a very small improvement. While this measured effect in this analysis is marginal, it should not be taken to imply that increasing tree density will not significantly increase crop yield. Most households in the sample had low tree density - as would be expected at baseline - and there may be insufficient variation among households for the model to pick up a stronger positive effect. There is ample research (mainly based on longitudinal studies) reporting yield benefits through optimization of tree species and density in parkland systems (e.g. see Binam et al. 2015). For example, increasing density of Faidherbia albida has been shown to improve grain and biomass yields in rainfed cereal cropping in dryland East Africa. In addition, different tree species impose positive or negative effects on dryland cereal crop production - and these effects vary with tree density and management, tree location on the field, crop type and seasonal conditions (Weston et al., 2015).

The model includes a set of variables representing the different mix of household members. The estimates suggest a strong positive impact of working age adults - every extra adult yields an additional 0.051 ha worth of crop production. This is similar in magnitude to the impact of an extra hectare of land (0.061). However, the 'interaction' variable defined as the product of land area and number of working aged adults has a negative coefficient, suggesting diminishing returns to extra land and extra adult labour. Put simply, if both the amount of land and adult labour doubled, this variable suggests the crop production would much less than double, highlighting other important constraints such as very limited availability of crop inputs.

Notably, additional children in the household also leads to higher production, but with less than half the magnitude of effect of adults. Why would the presence of children in the household affect crop production? There are demand and supply effects at work here. Regarding demand, more children means a greater demand for food and hence production, so may induce adults to work more productively. On the supply side, children can add to the household's labour supply, although they are not likely to be as productive as adults. Conversely, care for children can reduce the capacity of adults to work on their agricultural activities, meaning a negative effect on production. The net effect of these factors is a significant positive impact of children on production, suggesting children (of certain 
ages at least) are clearly relied upon as sources of productive labour in the household, or have a demand-pull effect on adult crop production. The responsibilities of caring for children are not a dominant factor leading to lower crop production in households with more children.

The third category of household members are the elderly. The same possible channels of effect on crop production apply here as with children. More elderly means greater demand for food, and they may be able to add to labour productivity if they are physically able, but can also add to the burden of care for other adults as they age. The significant negative effect found here suggests that on average, care responsibilities for the elderly outweigh the benefits they bring in terms of additional labour to assist with crop production or demand pull effects. This is not to suggest that elders are always a net burden: the estimate here is an on-average effect, with much variation in specific cases. The overall/average effect suggests a number of policy implications; for example, it supports the need for social transfers targeted at the elderly.

The regional indicator variables are all compared to the base region of Uganda (Kibale). The strong positive effect for the Kiambogoko region in Kenya is consistent with this being an area relatively dependent on crop production, while the opposite is true for Kotido in Uganda which is traditionally a pastoralist area.

\section{Livestock Assets}

The results in the second column of Table 5 show that, as with crop production, there is a strong positive impact of land area: more land means more stock of animals. There is an additional positive effect of land size via the interaction term with the number of working age adults. For a typical household of two working age adults, together these suggest diminishing returns to land, in that an extra hectare of land translates to only 0.145 more livestock units. This is a stronger effect than for crop production, but still suggestive of decreasing returns. The existence of a stronger effect is consistent with a labour constraint explanation for low crop production, as one would expect caring for animals to be less labour intensive than crop production. Other constraints to increasing livestock assets include limited supplies of fodder (crop residue and cut and carry forage) and water access for livestock, as well as diseases - reflecting inherent limitations of the mixed rainfed farming systems in the study areas.

Increased reliance on livestock assets does not seem to be associated with having more working age adults. Instead, households with more children and elderly adults tend to have higher levels of livestock, supporting the view that caring for animals is less physically demanding than managing field crops, hence suited to children and older household members.

The variables that allow for differential effects across the regions suggest that the Mogotio area of Kenya has a much higher median LUs than other areas, almost 3.5 LUs more than the base region of Uganda. The semi-arid area of Mogotio is largely a livestock production area.

\section{Crop Yields per Hectare}

The last column in Table 5 presents a model of crop yields per hectare, capturing productivity; that is, the ratio of production to FAO-reported Kenyan national average.

Greater land area is associated with lower yields. This is consistent with earlier discussion of the decreasing returns to land area. It appears that households with bigger farms have to spread their inputs further or apply them only to some areas, and possibly deal with more marginal land, so yields per hectare are significantly lower.

Tree density in this model is measured as simply the number of trees per hectare, since the output variable is measured on a per hectare basis. We observe that tree density has a significant positive impact on yields, although the effect is small. Note that tree species was not factored into the analysis, and as mentioned different species impact differently on crop yields. At this baseline stage of an intervention both tree species mix and tree density would not be expected to be optimal.

In the yield equation we concentrate on the role of working age adults in the household, including both the number of adults and the number per hectare. The adults per hectare variable shows a strong positive impact of more labour being available to work a fixed amount of land, suggesting labour constraints are binding. The number-of-adults variable shows a small negative effect, though, which suggests a diminishing benefit from additional adults as the number of adults increases.

\subsection{Welfare Models}


The next set of models considers various welfare measures, related to children in particular. In these child well-being models, the key explanatory variables are given here.

- Crop production: One would expect that a subsistence household that produces more food crops would experience better child welfare outcomes.

- Livestock: The greater the stock of animals, the more access the household has to potential food and income, which ought to improve welfare outcomes.

- Land area (hectares): Given crop and livestock production are already included in the model, this variable captures an additional asset/wealth effect of ownership of more land, above and beyond the production/income benefits the land brings.

- Household composition: It is common in subsistence agricultural households for the mix of adults and children in a household to be an important contributor to welfare.

- Quality of roofing: It is very likely that among poor rural households, overall household wealth will be associated with improved child welfare outcomes. Housing quality is a well-documented indicator of poverty, with more durable materials such as corrugated iron sheets (for roofing) indicating greater wealth. The survey places roofing into three categories: roofing with iron sheets in new condition ( 25.5 per cent of houses); iron sheets not in new condition ( 48.1 per cent); and other inferior types of roofing such as thatching or grass (26.4 per cent).

\section{Resilience}

Results for the model of resilience are given in the first column of Table 6. Considering the first set of variables, there is evidence that resilience improves as crop production increases. However, the effect is very small - an extra hectare-equivalent of crop production (more than doubling crop production for most households) increases the probability of being able to meet children's basic needs by 1.7 percentage points. For stock of animals, the effect is even smaller, and not statistically significant. In other words, the farm production of the 60 per cent of households who can meet their children's basic needs is only slightly higher than that of those who are not able to meet their needs. It is not productive activity that drives the differences between these households.

Table 6 near here

In contrast, land size appears to be an important factor, with statistical significance and much larger impacts on the likelihood of resilience than higher farm production. Similarly, the type of roofing on the family home has a strong correlation with resilience. For example, compared to those with thatched or grass roofed mud and wattle huts, a household with new iron sheeting is 16.9 percentage points more likely to be able to meet these basic needs. The type of roofing can serve as a good proxy for overall accumulated wealth and social status, so it is not surprising that it plays a role in household resilience. These effects are present even after taking account of differences in farm production - comparing two households with the same levels of production, the one with greater land size and better quality housing will have significantly greater resilience. The results suggest that long-term economic and social standing seems to be the main determining factor in being able to provide the basic needs of children.

Household composition variables tell an interesting story: more working age adults improve the likelihood of a child having their basic needs met (by 2.3 percentage points for every extra adult), but the presence of an additional elderly adult leads to a decline in likelihood of almost 10 percentage points. It appears that the needs of elderly adults compete with those of children when resources are scarce.

\section{Food Shortages}

The model reported in Columns 2 and 3 of Table 6 is based on a survey question asking whether the household experienced any serious food shortages over the past year, and the number of months households experienced these shortages.

Results show that households with more crop production have fewer food shortages, but again, the effect is quite small. An on-average doubling of crop production reduces incidence of food shortages by only 3.2 percentage points, with durations shorter by 0.122 months. Furthermore, animal stock has 
an even weaker association with both the likelihood of shortage and the number of months of shortages.

As with the resilience model, land size is an important factor, with significant effects on incidence of food shortage. This supports the view that land ownership gives benefits beyond just making higher production levels possible: land provides an asset/credit/reputation/status, that helps protect against vulnerability.

A similar story applies to the type of roofing on a house. Compared to those with a thatched or grass roof, households with new iron sheeting are 12.1 percentage points less likely to experience food shortages, and experience shortages for an average of 0.39 months less per year.

Household composition is an important contributor to food shortages, with more dependents (children and elderly) being associated with higher likelihood of food shortages and longer periods of shortage. The net effect of having more working age adults in the household is neutral - their presence neither increases nor reduces the food shortage problem. Their contribution to increased food production appears to be neutralized by the fact that they also contribute to the demand for food. This is indicative of the low productivity of labour in these subsistence households.

\section{Children in School}

In 65 per cen of households, all school-aged children regularly attend school. The estimated model includes a few additional factors not included in the resilience and food shortage models. First, we refine the household composition variable to focus on the number of school-aged children in the household, on the basis that a resource-constrained household with more school-aged children will find it more difficult to get all of these children to school. Secondly, a major contributing factor to children's engagement with school is the level of education of their parents. So we include variables to capture the level of education attained by the household head, comparing those who have primary education or secondary education with the base of no schooling.

Results suggest that in this sample, there is no clear connection between the primary sources of food and income - levels of crop production or animal stocks - and school attendance. The wealth/status variables of land size and quality of roofing show some association with school attendance, but the impacts are generally much weaker than those for food shortages or resilience.

When the household head has had some school education, this suggests children are more likely to be attending school regularly, although the effect is quite weak, and further analysis shows it is not consistent across all the regions.

The negative effect of number of school-aged children is not surprising, suggesting households are resource-constrained, and that the more children they have, the harder it is to be able to send them all to school. This is referred to as the quantity-quality trade-off in literature on the economics of education (Hanushek, 1992).

The model estimates suggest that having more working-aged adults in the household frees up the children to attend school. Households with few adults may face financial constraints, or children have to assume more responsibilities in the household. Note, however, that the effect is weak: an extra adult in the household increases the likelihood of all children being in school by 2.9 percentage points. This contrasts with the decrease of more than 8 percentage points for each additional child in the household.

\section{Summary and Conclusion}

The rural subsistence household represents an interesting study in household economic activity and household welfare. The purpose of this paper has been to consider the integration of these activities in the context of a sample of agricultural households across three countries in Africa.

To give a context to the characteristics of the regions from which this sample is taken, there is a common theme of low agricultural productivity, even compared to regional averages. Households are generally not producing sufficient food to meet their nutritional needs, and there are significant periods of the year where households experience food shortages, for an average of 3 months per year. The sampled areas would appear to be well selected for interventions designed to improve livelihoods and welfare outcomes.

Households who are doing best in terms of child welfare outcomes - meeting of basic needs, food security and education - tend to own more land and have good quality housing. This appears to be 
even more important than higher levels of farm production. This finding is consistent with an explanation that as ownership of assets (land, housing) is related to wealth and social status, and this increases social influence and access to resources that allow households to experience better welfare outcomes. It also suggests that interventions that focus purely on improving production and livelihoods may not be adequate for improving outcomes for children unless they can build a longterm base of assets for households.

The analysis suggests that households show a reasonably high commitment to schooling, although the greatest engagement is to primary school level education, with much lower attendance rates among older children. The link from parental education to child schooling is unusually weak, suggesting that for many families, these children are the first generation with widespread access to education, and the importance of basic education is well recognized. Having said that, households face constraints/costs associated with access to education, indicated by the lower attendance rates among families with more children.

Bringing together the results on agricultural productivity and household composition, the critical issue for economic and social development among these communities is to improve the productivity of both land and labour. How do we draw this conclusion? Consider first the production models: they suggest that yields per hectare decline significantly with land size, and equivalently, production is not much higher for households with larger areas available for crop production. This suggests two things: first, land quality may be poor so that additional land does not make a substantial difference to production. Secondly, it suggests a labour constraint in agricultural activity: providing more land does not lead to increased production because there is insufficient return on labour to justify the additional work involved in cultivating the extra land, given the typically low-input, labour-intensive farming methods. On the consumption side of the household economy, the food shortage models show that adult labour is relatively unproductive: having more adults in the household makes little difference to the incidence of food shortages. This suggests that the labour contributions of additional adults are barely sufficient to cover their own food needs, let alone create a surplus available for other household members.

Land and labour productivity constraints are usually related to land quality and unproductive labour activities. Poor land quality is driven by quality of soil, rainfall variability, and shortage of inputs designed to improve soil fertility. Meanwhile, poor labour productivity can relate to unproductive traditional agricultural practices, and lack of access to productive tools and equipment. There is a need to invest in assets that improve the productivity of land and labour. This allows more to be produced with the same or less labour input, which in turn frees up children to benefit from schooling, and adults to pursue other income producing activities. Practice change brought about through successful Farmer Managed Natural Regeneration programmes will also restore degraded land, in addition to improving land and labour productivity.

It is also important to recognize that within communities, there are households with significantly more assets (mainly land, quality housing and animals) than others. These households are more able to provide for their family's basic needs. This points clearly to interventions that focus on the poor and vulnerable within communities, avoiding implementation that allows capture by the local 'elite'.

Page and Shimeles (2015) make a strong case for focusing aid and development in Africa on the transition from low-productivity to high-productivity employment. They show that this is the critical factor in poverty reduction, and argue further that the key first step is ' ... more aid is needed to raise agricultural productivity and income' (Page and Shimeles, 2015, p. 18). This paper confirms this link from productivity to poverty reduction, gives some insights into the binding constraints to improving productivity, and highlights the need for progress as a key to improving children's social and economic opportunities.

\section{References}

Angrist, J. and J. Pischke (2009), Mostly Harmless Econometrics, Princeton University Press, Princeton, NJ.

Binam, J. N., F. Place, A. Kalinganire, S. Hamade, M. Boureima, A. Tougiani, J. Dakouo, B. Mounkoro, S. Diaminatou, M. Badji, M. Diop, A. Babou and E. Haglund (2015), 'Effects of Farmer 
Managed Natural Regeneration on Livelihoods in Semi-arid West Africa', Environmental Economics and Policy Studies, Vol. 17, pp. 543-75.

Boffa, J. M. (1999), Agroforestry Parklands in Sub-Saharan Africa, FAO Conservation Guide 34.

Chilonda, P. and J. Otte (2006), 'Indicators to Monitor Trends in Livestock Production at National, Regional and International Levels', Livestock Research for Rural Development, Vol. 18, No. 8, Article 117.

Christiaensen, L. and K. Subbarao (2005), 'Towards an Understanding of Household Vulnerability in Rural Kenya', Journal of African Economies, Vol. 14, pp. 520-58.

Christiaensen, L., L. Demery and J. Kuhl (2011), 'The (Evolving) Role of Agriculture in Poverty Reduction: An Empirical Perspective', Journal of Development Economics, Vol. 96, pp. 239-54.

Codjoe, S. and F. Dzanku (2009), 'Long-term Determinants of Deforestation in Ghana: The Role of Structural Adjustment Policies', African Development Review, Vol. 21, pp. 558-88.

Conceicao, P., R. Fuentes-Nieva, L. Hoen-Phathanothai and A. Ngororano (2011), 'Food Security and Human Development in Africa: Strategic Considerations and Directions for Further Research', African Development Review, Vol. 23, pp. 237-46.

Datt, G. and M. Ravallion (1998), 'Farm Productivity and Rural Poverty in India', The Journal of Development Studies, Vol. 34, pp. 62-85.

Diao, X. and D. Sarpong (2011), 'Poverty Implications of Agricultural Land Degradation in Ghana: An Economy-wide, Multimarket Model Assessment', African Development Review, Vol. 23, pp. 26375 .

Dzanku, F. (2015), 'Household Welfare Effects of Agricultural Productivity: A Multidimensional Perspective from Ghana', The Journal of Development Studies, Vol. 51, pp. 1139-54.

Fafchamps, M. (2010), 'Vulnerability, Risk Management and Agricultural Development', African Journal of Agricultural Economics, Vol. 5, No. 1, pp. 243-60.

FAO (2011), The State of the World's Land and Water Resources for Food and Agriculture (SOLAW) - Managing Systems at Risk, Food and Agriculture Organization of the United Nations, Rome and Earthscan, London.

Gakusi, A. (2010), 'African Education Challenges and Policy Responses: Evaluation of the Effectiveness of the African Development Bank's Assistance', African Development Review, Vol. 22, pp. 208-64.

Hanushek, E. (1992), 'The Trade-off between Child Quantity and Quality', The Journal of Political Economy, Vol. 100, pp. 84-117.

Immink, M. and J. Alarcon (1993), 'Household Income, Food Availability, and Commercial Crop Production by Smallholder Farmers in the Western Highlands of Guatemala', Economic Development and Cultural Change, Vol. 41, pp. 319-42.

Jayne, T., T. Yamano, M. Weber, D. Tschirley, R. Benfica, A. Chapoto and B. Zulu (2003),

'Smallholder Income and Land Distribution in Africa: Implications for Poverty Reduction Strategies', Food Policy, Vol. 28, pp. 253-75.

Meinzen-Dick, R., J. Behrman, P. Menonand, and A. Quisumbing (2012), 'Gender: A Key Dimension Linking Agricultural Programs to Improved Nutrition and Health', in S. Fan and R. Pandya-Lorch, Reshaping Agriculture for Nutrition and Health, pp. 135-44.

Njuki, J., J. Poole, N. Johnson, I. Baltenweck, P. Pali, Z. Lokman and S. Mburu (2011), Gender, Livestock and Livelihood Indicators, International Livestock Research Institute.

Nolan, S. (2013), East Africa Region Farmer Managed Natural Regeneration Program Draft Baseline Report, World Vision International. 
Page, J., and A. Shimeles (2015), 'Aid, Employment and Poverty Reduction in Africa', African Development Review, Vol. 27, pp. 17-30.

Reij, C., G. Tappan and M. Smale (2009), 'Agroenvironmental Transformation in the Sahel: Another Kind of Green Revolution’, IFPRI Discussion Paper 00914.

Rousseeuw, P. and A. Leroy (1987), Robust Regression and Outlier Detection, Wiley, New York.

Schneider, K. and P. Gugerty (2011), 'Agricultural Productivity and Poverty Reduction: Linkages and Pathways', The Evans School Review, Vol. 1, pp. 56-74.

Shapiro, R. (1990), 'Farm Size, Household Size and Composition, and Women's Contribution to Agricultural Production: Evidence from Zaire', Journal of Development Studies, Vol. 27, pp. 1-21.

Taylor, J. E. and I. Adelman (2003), 'Agricultural Household Models: Genesis, Evolution, and Extensions', Review of Economics of the Household, Vol. 1, pp. 33-58.

Tirivayi, N., M. Knowles and B. Davis (2016), 'The Interaction between Social Protection and Agriculture: A Review of Evidence', Global Food Security, Vol. 10, pp. 52-62.

Townsend, R. (1995), 'Consumption Insurance: An Evaluation of Risk-Bearing Systems in LowIncome Countries', Journal of Economic Perspectives, Vol. 9, pp. 83-102.

Valdes, A. and W. Foster (2010), 'Reflections on the Role of Agriculture in Pro-poor Growth', World Development, Vol. 38, pp. 1362-74.

Weston, P., R. Hong, C. Kabore and C. Kull (2015), 'Farmer-Managed Natural Regeneration Enhances Rural Livelihoods in Dryland West Africa', Environmental Management, Vol. 55, No. 6, pp. 1402-17.

Weston, P., R. Hong and V. Morrison (2013), 'Talensi FMNR Project: End-of-Phase Evaluation Report', World Vision Australia and World Vision Ghana.

World Vision Australia (2015), 'FMNR: Farmer Managed Natural Regeneration', fmnr.com.au/home/about-us (accessed 10 April 2015). 
Table 1: Basic characteristics of each region

\begin{tabular}{ccc}
\hline Kenya & Kiambogoko: & Mogotio: \\
& relatively high and reliable average & - average rainfall $300-750 \mathrm{~mm}$, \\
rainfall $(840 \mathrm{~mm}$ pa $)$ & much less reliable. \\
- undulating topography, elevation & - agricultural yields are relatively \\
of $2,500-3000 \mathrm{~m}$ & low \\
- small land sizes per capita & - greater reliance on pastoralism \\
compared to Mogotio & or casual labour in regional \\
- locations close to elevated forests,, & centres. \\
reliance on wild foods &
\end{tabular}

\section{Number of households:411}

\section{Number of households:431}

\section{Tanzania Kongwa:}

- a maize producing region in the Central Rift Valley

\section{Other areas}

\section{(Kilimatinde, Mpwapwa,} Mundemu):

- a semi-arid area with bi-modal rainfall (500 $\mathrm{mm}$, variable)

- a semi-arid climate with average rainfall of 450 to $700 \mathrm{~mm}$.

- growing season of 8 months

- rich permeable soils suitable for producing a diverse range of outputs

- average land sizes are smaller than Kongwa

- has experienced high rates of deforestation

- relatively large average farm sizes

Number of households: 450

Number of households: $\mathbf{1 , 3 5 0}$

\section{Uganda Kotido:}

- traditional territories of the Jie, a tribal pastoralist group

\section{Other areas}

- semi-arid and features mainly savannah grasses

(Kibaale, Nalweyo Kisiita, Masaka):

- has experienced significant deforestation

- low annual rainfall (averaging 800 $\mathrm{mm}$ )

- located within the Central Plateau, an altitude of 680 $1500 \mathrm{~m}$ 


\author{
- tropical climate, 1000-1500 mm \\ of semi-reliable rainfall \\ annually \\ - relatively large land sizes
}

\title{
Number of households: 455
}

Number of households: 411 
Table 2: FAO average crop yield per hectare, Kenya 2013

\begin{tabular}{ccc}
\hline Crop & & $\begin{array}{c}\text { Average yield } \\
\text { Kilogram per hectare }\end{array}$ \\
& Maize & 1615 \\
Groundnut & 1471 \\
Millet & 641 \\
Sorghum & 660 \\
Beans & 529 \\
\hline
\end{tabular}

Table 3: Livestock units, sub-Saharan Africa

\begin{tabular}{cccccccc}
\hline Cattle & Sheep & Goats & Pigs & Asses & Horses & Mules & Chickens \\
\hline 0.50 & 0.10 & 0.10 & 0.20 & 0.30 & 0.50 & 0.60 & 0.01 \\
\hline
\end{tabular}

Source: Chilonda and Otte (2006). 
Table 4: Descriptive statistics for key variables

\begin{tabular}{|c|c|c|c|c|c|c|c|c|}
\hline & \multirow[b]{2}{*}{$\begin{array}{l}\stackrel{D}{D} \\
\stackrel{D}{D} \\
\stackrel{D}{D} \\
\stackrel{\bar{D}}{D}\end{array}$} & \multirow[b]{2}{*}{$\begin{array}{l}\text { All } \\
\text { Countries }\end{array}$} & \multicolumn{2}{|c|}{ Kenya } & \multicolumn{2}{|c|}{ Tanzania } & \multicolumn{2}{|c|}{ Uganda } \\
\hline & & & Kiambgoko & Mogotio & Kongwa & $\begin{array}{l}\text { Other } \\
\text { areas }\end{array}$ & Kotido & $\begin{array}{l}\text { Other } \\
\text { areas }\end{array}$ \\
\hline \multirow{3}{*}{$\begin{array}{l}\text { Crop } \\
\text { production (ha } \\
\text { equivalent) }\end{array}$} & 25th & 0.19 & 0.58 & 0.22 & 0.36 & 0.16 & 0.15 & 0.12 \\
\hline & 50th & 0.55 & 1.11 & 0.50 & 0.80 & 0.45 & 0.34 & 0.50 \\
\hline & 75th & 1.11 & 2.12 & 1.00 & 1.56 & 0.94 & 0.64 & 0.97 \\
\hline \multirow{3}{*}{$\begin{array}{l}\text { Animal stock } \\
\text { (ha equivalent) }\end{array}$} & 25th & 0.0 & 0.06 & 1.95 & 0.00 & 0.00 & 0.20 & 0.01 \\
\hline & 50th & 0.33 & 0.8 & 4.15 & 0.04 & 0.06 & 1.30 & 0.20 \\
\hline & 75th & 2.53 & 2.4 & 7.67 & 1.03 & 1.34 & 3.50 & 0.60 \\
\hline \multirow{3}{*}{ Land size (ha) } & 25th & 0.81 & 0.81 & 0.81 & 2.02 & 1.21 & 0.81 & 0.81 \\
\hline & 50th & 2.02 & 1.21 & 2.43 & 3.24 & 2.02 & 1.62 & 1.62 \\
\hline & 75th & 3.24 & 2.02 & 6.07 & 6.07 & 3.24 & 2.43 & 3.24 \\
\hline \multirow{3}{*}{$\begin{array}{l}\text { Number of } \\
\text { trees } \\
\text { (trees per farm) }\end{array}$} & 25th & 2 & 4 & & 2 & 2 & 3 & 3 \\
\hline & 50th & 5 & 19 & 3 & 5 & 4 & 10 & 11 \\
\hline & 75th & 14 & 60 & 6 & 10 & 8 & 21 & 27 \\
\hline \multirow{3}{*}{$\begin{array}{l}\text { Crop yield } \\
\text { ratio ( } 1.0=\text { Kenya } \\
\text { average) }\end{array}$} & 25th & 0.10 & .55 & 0.05 & 0.11 & 0.09 & 0.10 & 0.09 \\
\hline & 50th & 0.28 & .92 & 0.20 & 0.24 & 0.24 & 0.22 & 0.26 \\
\hline & 75th & 0.63 & 1.72 & 0.56 & 0.42 & 0.50 & 0.46 & 0.73 \\
\hline
\end{tabular}

Resilient

households

55

54

71

57

57

44

40

(\%)

Households

with food

76

71

66

64

81

93

58

shortages (\%)

25 th

1

0

0

0

2

4

0 


\begin{tabular}{|c|c|c|c|c|c|c|c|}
\hline \multirow{2}{*}{$\begin{array}{l}\text { Months of } \\
\text { food shortages }\end{array}$} & 50th & 4 & 4 & 4 & 4 & 6 & 6 \\
\hline & 75th & 8 & 6 & 6 & 6 & 8 & 10 \\
\hline $\begin{array}{l}\text { All children in } \\
\text { school (\%) }\end{array}$ & & 43 & 58 & 79 & 29 & 38 & 21 \\
\hline
\end{tabular}

Table 5: Median regression results for agricultural production

\begin{tabular}{|c|c|c|c|}
\hline Dependent variable & Crop production & Animal stock & Crop yields \\
\hline \multirow[t]{2}{*}{ Intercept } & 0.202 & -0.092 & 0.257 \\
\hline & $(3.98)^{* * *}$ & $(-3.14)$ & $(12.03)^{* * *}$ \\
\hline \multirow[t]{2}{*}{ Land area (ha) } & 0.061 & 0.041 & -0.005 \\
\hline & $(13.36)^{* * *}$ & $(15.24)^{* * *}$ & $(-4.95)^{* * *}$ \\
\hline \multirow[t]{2}{*}{ Tree density } & 0.00022 & -0.00017 & 0.00016 \\
\hline & $(4.34)^{* * *}$ & $(6.22)^{* * *}$ & $(4.06)^{* * *}$ \\
\hline \multirow{2}{*}{$\begin{array}{l}\text { Number of working age } \\
\text { adults in household }\end{array}$} & 0.051 & -0.013 & -0.023 \\
\hline & $(4.13)^{* * *}$ & $(-1.82)^{*}$ & $(-4.35)^{* * *}$ \\
\hline \multirow{2}{*}{$\begin{array}{l}\text { Number of children in } \\
\text { household }\end{array}$} & 0.021 & 0.029 & \\
\hline & $(3.65)^{* *}$ & $(8.76)^{* * *}$ & \\
\hline \multirow{2}{*}{$\begin{array}{l}\text { Number of elderly in } \\
\text { household }\end{array}$} & -0.061 & 0.069 & \\
\hline & $(-2.68)^{* * *}$ & $(5.16)^{* * *}$ & \\
\hline \multirow{2}{*}{$\begin{array}{l}\text { Land area * Number of } \\
\text { working age adults }\end{array}$} & -0.0023 & 0.052 & \\
\hline & $(-1.35)$ & $(51.30)^{* * *}$ & \\
\hline \multirow{2}{*}{$\begin{array}{l}\text { Number of working age } \\
\text { adults per hectare of land }\end{array}$} & & & 0.088 \\
\hline & & & $(29.31)^{* * *}$ \\
\hline \multirow[t]{2}{*}{ Kenya, Kiambogoko } & 0.676 & 0.581 & 0.555 \\
\hline & $(13.01)^{* * *}$ & $(19.27)^{* * *}$ & $(21.90) * * *$ \\
\hline Kenya, Mogotio & -0.063 & 3.54 & -0.049 \\
\hline
\end{tabular}




\begin{tabular}{lccc}
\hline & $(-1.21)$ & $(116.04)^{* * *}$ & $(-1.96)^{* *}$ \\
Tanzania, Kongwa & 0.257 & -0.161 & 0.008 \\
& $(5.00)^{* * *}$ & $(-5.38)^{* * *}$ & $(0.33)$ \\
Tanzania, others & -0.010 & -0.048 & -0.047 \\
& $(-0.23)$ & $(-1.95)^{*}$ & $(-2.28)^{* *}$ \\
Uganda, Kotido & -0.208 & 1.140 & -0.128 \\
& $(-3.65)^{* * *}$ & $(34.74)^{* * *}$ & $(-4.78)^{* * *}$ \\
Sample size & 3193 & 3247 & 3153
\end{tabular}

*,**,*** imply statistically significant at the $10 \%, 5 \%$ and $1 \%$ levels respectively. 
Table 6: Regression results for child welfare outcomes

\begin{tabular}{|c|c|c|c|c|}
\hline Dependent variable & Resilience & $\begin{array}{c}\text { Experiences } \\
\text { food shortages }\end{array}$ & $\begin{array}{l}\text { Months of food } \\
\text { shortages }\end{array}$ & $\begin{array}{l}\text { All children } \\
\text { in school }\end{array}$ \\
\hline Intercept & $\begin{array}{l}0.233 \\
(5.11)^{* * *}\end{array}$ & $\begin{array}{c}0.677 \\
(17.32)^{* * *}\end{array}$ & $\begin{array}{l}1.44 \\
(8.65)^{* * *}\end{array}$ & $\begin{array}{c}0.557 \\
(9.20)^{* * *}\end{array}$ \\
\hline Land area & $\begin{array}{l}0.031 \\
(5.76)^{* * *}\end{array}$ & $\begin{array}{l}-0.020 \\
(-4.33)^{* * *}\end{array}$ & $\begin{array}{l}-0.081 \\
(-4.06)^{* * *}\end{array}$ & $\begin{array}{c}0.015 \\
(2.42)^{* * *}\end{array}$ \\
\hline $\begin{array}{l}\text { Number of working-age adults } \\
\text { in household }\end{array}$ & $\begin{array}{c}0.023 \\
(2.76)^{* * *}\end{array}$ & $\begin{array}{l}-0.000 \\
(-0.05)\end{array}$ & $\begin{array}{l}0.002 \\
(0.08)\end{array}$ & $\begin{array}{c}0.029 \\
(2.99)^{* * *}\end{array}$ \\
\hline $\begin{array}{l}\text { Number of children in } \\
\text { household }\end{array}$ & $\begin{array}{l}-0.003 \\
(-0.63)\end{array}$ & $\begin{array}{l}0.017 \\
(4.61)^{* * *}\end{array}$ & $\begin{array}{l}0.056 \\
(3.49)^{* * *}\end{array}$ & \\
\hline $\begin{array}{l}\text { Number of school-aged } \\
\text { children in household }\end{array}$ & & & & $\begin{array}{c}-0.083 \\
(-11.63)^{* * *}\end{array}$ \\
\hline $\begin{array}{l}\text { Number of elderly in } \\
\text { household }\end{array}$ & $\begin{array}{l}-0.097 \\
(-5.65)^{* * *}\end{array}$ & $\begin{array}{c}0.026 \\
(1.78)^{*}\end{array}$ & $\begin{array}{c}0.168 \\
(2.62)^{* * *}\end{array}$ & $\begin{array}{l}0.000 \\
(0.00)\end{array}$ \\
\hline $\begin{array}{l}\text { Roofing: iron sheets (not new) } \\
\text { vs no sheets }\end{array}$ & $\begin{array}{l}0.092 \\
(4.18)^{*}\end{array}$ & $\begin{array}{l}-0.091 \\
(-4.80)^{* * *}\end{array}$ & $\begin{array}{l}-0.205 \\
(-2.53)^{* *}\end{array}$ & $\begin{array}{l}0.078 \\
(3.06)^{* * *}\end{array}$ \\
\hline $\begin{array}{l}\text { Roofing: new iron sheets vs no } \\
\text { sheets }\end{array}$ & $\begin{array}{c}0.169 \\
(5.65)^{* * *}\end{array}$ & $\begin{array}{l}-0.121 \\
(-4.53)^{* * *}\end{array}$ & $\begin{array}{l}-0.388 \\
(3.40)^{* * *}\end{array}$ & $\begin{array}{c}0.080 \\
(2.15)^{* *}\end{array}$ \\
\hline Impact of crop production & $\begin{array}{l}0.017 \\
(2.50)^{* *}\end{array}$ & $\begin{array}{l}-0.032 \\
(-5.20)^{* * *}\end{array}$ & $\begin{array}{l}-0.122 \\
(-4.66)^{* * *}\end{array}$ & $\begin{array}{l}-0.006 \\
(-0.90)\end{array}$ \\
\hline Impact of animal stock & $\begin{array}{r}0.005 \\
(1.50)\end{array}$ & $\begin{array}{l}-0.004 \\
(-1.67)^{*}\end{array}$ & $\begin{array}{l}-0.017 \\
(-1.77)^{*}\end{array}$ & $\begin{array}{l}-0.007 \\
(-2.42)^{* *}\end{array}$ \\
\hline $\begin{array}{l}\text { Household Head Education: } \\
\text { Primary vs None }\end{array}$ & & & & $\begin{array}{l}0.063 \\
(2.50)^{* *}\end{array}$ \\
\hline $\begin{array}{l}\text { Household Head Education: } \\
\text { Secondary vs None }\end{array}$ & & & & $\begin{array}{l}0.035 \\
(0.89)\end{array}$ \\
\hline
\end{tabular}




\begin{tabular}{lcccc}
\hline Kenya, Kiambogoko & 0.096 & 0.157 & 0.701 & 0.111 \\
Kenya, Mogotio & $(2.31)^{* *}$ & $(3.94)^{* * *}$ & $(4.12)^{* * *}$ & $(1.96)^{* *}$ \\
& 0.246 & 0.122 & 1.045 & 0.306 \\
Tanzania, Kongwa & $(5.91)^{* * *}$ & $(3.01)^{* * *}$ & $(6.05)^{* * *}$ & $(5.21)^{* * *}$ \\
& 0.099 & 0.144 & 1.285 & -0.254 \\
Tanzania, other & $(2.46)^{* *}$ & $(3.78)^{* * *}$ & $(7.89)^{* * *}$ & $(-4.56)^{* * *}$ \\
& 0.173 & 0.212 & 1.468 & -0.139 \\
Uganda, Kotido & $(5.11)^{* * *}$ & $(6.37)^{* * *}$ & $(10.35)^{* * *}$ & $(-2.77)^{* * *}$ \\
Sample size & 0.027 & 0.242 & 1.548 & -0.201 \\
\hline & $(0.62)$ & $(5.85)^{* * *}$ & $(8.76)^{* * *}$ & $(-3.28)^{* * *}$ \\
\hline
\end{tabular}

*, **, *** imply statistically significant at the $10 \%, 5 \%$ and $1 \%$ levels respectively.

Outliers excluded (land $>10$ ha; farm production $>30$ ha; trees per ha $>300$ ). 
Queries to author

1. Please provide reference details for Ravallion 2009, Bresciani and Valde 2007, Minten and Barrett 2008, Bunswanger and Rosenzweig 1986, Peterman et al. 2011

2. You refer to Meinzen-Dick et al. 2011 but the reference list has 2012 - which one is the correct year? Please also provide publisher and place of publication.

3. The last paragraph of section 4 has 'Four measures are used:' but there are only three bullet points. Please clarify. 


\section{University Library}

\section{- M M N E R VA A gateway to Melbourne's research publications}

Minerva Access is the Institutional Repository of The University of Melbourne

Author/s:

Inder, B;Kabore, C;Nolan, S;Cornwell, K;Suarez, DC;Crawford, A;Kamara, JK

Title:

Livelihoods andChild Welfare among Poor Rural Farmers in East Africa

Date:

2017-06-01

Citation:

Inder, B., Kabore, C., Nolan, S., Cornwell, K., Suarez, D. C., Crawford, A. \& Kamara, J. K. (2017). Livelihoods andChild Welfare among Poor Rural Farmers in East Africa. AFRICAN DEVELOPMENT REVIEW-REVUE AFRICAINE DE DEVELOPPEMENT, 29 (2), pp.169-183. https://doi.org/10.1111/1467-8268.12248.

Persistent Link:

http://hdl.handle.net/11343/292977 